\title{
The Value of Lung Ultrasound Score Predicts the Ventilator use in Preterm with Dyspnea within 24h after Hospitalization
}

\section{Research Article}

Keywords:

Posted Date: April 20th, 2022

DOI: https://doi.org/10.21203/rs.3.rs-1203352/v2

License: (c) (i) This work is licensed under a Creative Commons Attribution 4.0 International License.

Read Full License 


\section{Abstract}

The full text of this preprint has been withdrawn by the authors as it was submitted and made public without the full consent of all the authors. Therefore, the authors do not wish this work to be cited as a reference. Questions should be directed to the corresponding author.

\section{Full Text}

The authors have withdrawn this preprint from Research Square. 